\title{
DNA Binding Studies of Ternary Copper (II) Complexes of Doxycycline with Polypridyl Ligands
}

\author{
Joshua A. Obaleye ${ }^{1 *}$ and Olufunso O. Abosede ${ }^{2}$
}

\author{
${ }^{1}$ Department of Chemistry, University of Ilorin, P.M.B. 1515, Ilorin,Kwara State, Nigeria \\ ${ }^{2}$ Department of Chemistry, Federal University Otuoke, P.M.B. 126, Yenagoa, Bayelsa State, Nigeria. \\ * Corresponding Author
}

\begin{abstract}
Tetracyclines are a family of drugs with interesting pleiotropic properties. The recognition by scientists of the therapeutic properties and safety profile of this class of drugs has led to the continuous derivatization of these compounds and implementation of clinical trials to explore their potential applications for a wide range of diseases. To this end, this paper review literature on tetracyclines from the discovery of the first tetracycline to a new class of tetracyclines called glycylcyclines. The DNA binding propensities of some copper (II) complex of doxycycline and mixed ligand copper (II) doxycycline complexes with polypyridyl ligands were also investigated by UV-Vis titration, viscosity and thermal melting experiments. The mixed ligand copper (II) doxycycline complexes with polypyridyl ligands were found to bind CT DNA in the major groove in a similar fashion to methyl green causing no change in the viscosity and negligible increase in thermal melting of CT DNA.
\end{abstract}

Keywords- copper (II), doxycycline, polypyridyl, DNA binding, complex.

\section{INTRODUCTION}

7-chlorotetracycline was the first tetracycyline discovered, extracted from Streptomyces aureofaciens present in soil by Benjamin M Duggar in 1948 and named aureomycin [13]. Two years later Terramycin (5-hydroxytetracycline) was isolated by fermentation of the actinomycete, Streptomyces rimosusby Finlay and coworkers [4,5]. Catalytic hydrogenolysis of aureomycin was reported to produce the parent tetracycline [6,7] which was later prepared by fermentation of certain strains of Streptomyces alboniger[8].In 1955, Conover patented tetracycline which became the most prescribed broad-spectrum antibiotic in the U.S within three years, and because of their great therapeutic value and wide application the tetracyclines have received a great deal of attention and is the object of several reviews [9-13]. The studies on tetracyclines include synthesis of novel tetracyclines and improved methodology [14-20], their clinical applications [10,11,21], uptake, mechanisms of action [9, 21-22], resistance [23-28], metal chelation [29-34], environmental impact, detection and removal [35-38]. The rise in drug-resistant bacteria has also led to new approaches to antibiotic development including the development of novel pharmaceuticals such as doxycycline and novel tigecycline [39], the first member of a new class of tetracyclines named glycylcyclines.

Besides the use of tetracyclines as broad-spectrum antibiotics new uses have emerged including their potential use in anticancer therapy [40-49]. Tetracyclines inhibit matrix metalloproteinases MMPs [44,50] and are also effective but slow-acting anti-malarial drugs [41,51]. At concentrations within the therapeutic levels, tetracyclines inhibited production of reactive oxygen species (ROS) which account, in part, for their anti-inflammatory action such as in acne or vulgaris [52]. Minocycline is a proven antioxidant with radical scavenging potency similar to vitamin E [53,54] because of its many substituted phenol rings.Of the tetracyclines, doxycycline is the most commonly used [44], a more potent MMP inhibitor, better absorbed and with longer half-life than the parent compound, tetracycline [55].It has been found that doxycycline reduces the in vitro growth of human breast cancer by $70 \%[55,56]$ as well as prostate cancer cells [57]. The binding of tetracyclines with proteins was found to be greatly enhanced when complexed with divalent metal ions $[58,59]$. The potency of tetracyclines as MMP inhibitors is also positively related to their chelation to metal ion at the active site of the MMPs [60-61].

Moreover, several metal complexes have been used as artificial chemical nucleases among which copper nucleases 
especially copper diimine complexes have been a wellresearched class of syntheticmetallonucleases and widely tested anticancer agents. The therapeutic properties of copper, the wide application of doxycycline, and DNA binding and cleavage abilities of diimine ligands prompted us to synthesize and investigate biological activities of mixed copper complexes containing doxycycline and polypyridyl ligands.

\section{EXPERIMENTAL SECTION}

Materials and Measurements

Doxycycline hyclate was obtained from Neimeth International Pharmaceuticals Plc, Nigeria and fresh solutions were used to ensure stability. Copper nitrate trihydrate and Tris(hydroxylmethyl) aminomethane- $\mathrm{HCl}$ (Tris-HCl) were from Qualigens while 2,2'-bipyridine and 1,10-phenanthroline monohydrate were from SDFCL, India. The ligands dipyrido[3,2-d:2',3'-f]quinoxaline (dpq) [67] and dipyrido[3,2-a:2',3'-c]phenazine (dppz) [68] were synthesized according to reported procedure [1]. Calf thymus DNA sodium salt (CT DNA) was used as obtained from SRL, India. All other chemicals and reagents are of analytical grade and used without further purifications. The metal complexes were synthesized according to previous published reports [69]. UV-Vis absorption measurements were carried out on Jasco V-630 spectrophotometer. $2.0 \times$ $10^{-5}$ mol $\mathrm{L}^{-1}$ of doxycycline and complex concentrations were used.

\section{DNA Binding Studies}

The DNA binding experiments were performed in Tris$\mathrm{HCl} / \mathrm{NaCl}$ buffer $(5 \mathrm{~mol} \mathrm{~L}-1$ Tris-HCl/ $50 \mathrm{~mol} \mathrm{~L}-1 \mathrm{NaCl}, \mathrm{pH}$ 7.2). The concentration of CT-DNA was calculated from its known extinction coefficient at $260 \mathrm{~nm}\left(6600 \mathrm{M}^{-1} \mathrm{~cm}^{-1}\right)$. Solutions of CT-DNA in buffer gave a ratio of UV absorbance at $260 \mathrm{~nm}$ and $280 \mathrm{~nm}\left(\mathrm{~A}_{260} / \mathrm{A}_{280}\right)$ 1.8-1.9 indicating that the DNA was sufficiently free of protein.

Eectronic absorption titration. The electronic absorption spectra of $2 \times 10^{-5} \mathrm{~mol} \mathrm{~L}^{-1}$ of the complexes with increasing concentration of nucleotide $\left(1.0 \times 10^{-5}-1.5 \times 10^{-4} \mathrm{~mol} \mathrm{~L}^{-1}\right)$ were recorded in buffer following reported procedures [7071]. The solutions were allowed to equilibrate for 20 minutes at room temperature after addition of DNA to the metal complex before absorption readings were taken. Binding constants of complexes were determined according to equation 1 [72-73]

$$
[\mathrm{DNA}] /\left[\varepsilon_{\mathrm{a}}-\varepsilon_{\mathrm{b}}\right]=[\mathrm{DNA}] /\left[\varepsilon_{\mathrm{b}}-\varepsilon_{\mathrm{f}}\right]+1 / \mathrm{K}_{\mathrm{b}}
$$

$\left[\varepsilon_{b}-\varepsilon_{f}\right]$

(1)
Where [DNA] is the concentration of DNA in base pairs, $\varepsilon_{\mathrm{a}}$ is the extinction coefficient observed for the MLCT absorption band at the given DNA concentration, eis the extinction coefficient of the free (unbound) complex and $\varepsilon_{b}$ is the extinction coefficient of the fully bound complex. The ratio of the slope $1 /\left[\varepsilon_{\mathrm{a}}-\varepsilon_{\mathrm{f}}\right]$ and the intercept $1 / \mathrm{K}_{\mathrm{b}}\left[\varepsilon_{\mathrm{b}}-\varepsilon_{\mathrm{f}}\right]$ obtained from a plot of [DNA] / [ $\left.\varepsilon_{\mathrm{a}}-\varepsilon_{f}\right]$ versus [DNA] gives the intrinsic binding constant [73].

$1 \times 10^{-3} \mathrm{~mol} \mathrm{~L}^{-1}$ stock solutions of the complexes $\mathbf{1 , 2 , 3}$ were prepared in buffer while complexes $\mathbf{4}$ and $\mathbf{5}$ were prepared in doubly distilled water and diluted suitably with buffer to required concentrations.

\section{Thermal melting experiments}

DNA melting experiments were carried out by monitoring the absorption at $260 \mathrm{~nm}$ of CT DNA $\left(1.0 \times 10^{-4} \mathrm{~mol} \mathrm{~L}^{-1}\right)$ with a JASCO V-630 spectrophotometer equipped with a Peltier temperature controlling programmer ETC-717 (). $1{ }^{\circ} \mathrm{C}$ from $28{ }^{\circ} \mathrm{C}$ to $95^{\circ} \mathrm{C}$ in the presence and absence of the complexes.

\section{Viscosity meas urements}

Viscosity measurements were carried out using a semimicroviscometer. The flow time was measured with a digital stopwatch, and each sample was measured four times and an average flow time was calculated. Data are presented as $\left(\eta / \eta^{0}\right)^{1 / 3}$ versus the ratio [complex]/[DNA], where $\eta$ is the viscosity of DNA in the presence of complex and $\eta^{0}$ is the viscosity of DNA alone.

Viscosity values were calculated from the observed flow time of DNA-containing solutions corrected for the flow time of buffer alone $\left(\mathrm{t}^{0}\right): \mathrm{n}=\mathrm{t}-\mathrm{t}^{0}[74]$

\section{DNA Binding Studies}

\section{RESULTS AND DISCUSSION}

Upon the addition of a solution of calf thymus (CT) DNA to the copper (II) complexes, a decrease in the absorption intensities of the $\pi-\pi^{*}$ absorption bands (250-400) of 2 5 was observed. As theextent of hypochromism is commonlyas sociated with the strength of DNA interaction, this indicates strong DNA binding of the complexes.

In order to quantitatively compare the DNA binding affinities of the complexes, their intrinsic binding constants with CT-DNA were obtained by monitoring the intraligand band absorption with increasing concentration of DNA using equation 1 and were found to be $7.26 \times 10^{4}, 6.7 \times 10^{4}$, $2.58 \times 10^{5}$ and $6.18 \times 10^{4}$ for complexes $\mathbf{5 , 4 , 3}$ and 2 respectively. The fact that complex $\mathbf{3}$ has the highest binding constant shows that a binding mode other than intercalation is involved. The hypochromic shifts observed 
upon increasing concentration of DNA is likely to arise from surface aggregation of $\pi$-stacking interactions of the cationic complexes.

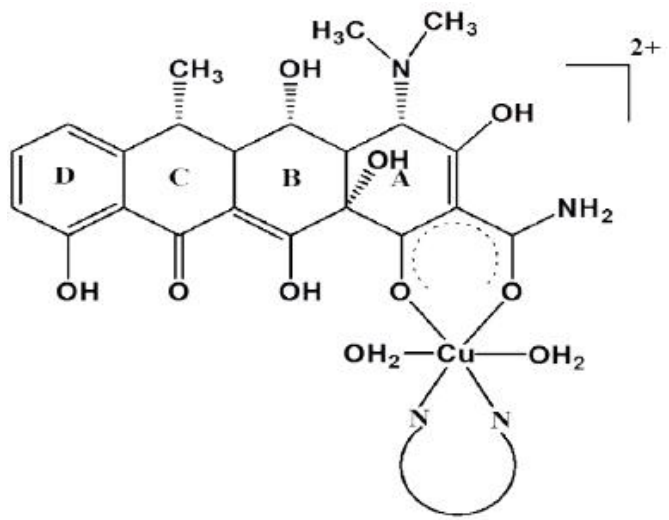

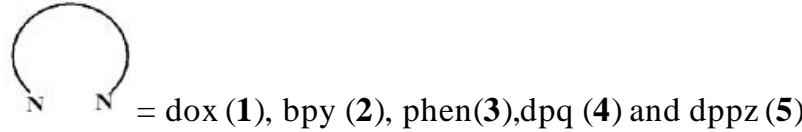

Fig.1: structures of the studied compounds ${ }^{75}$

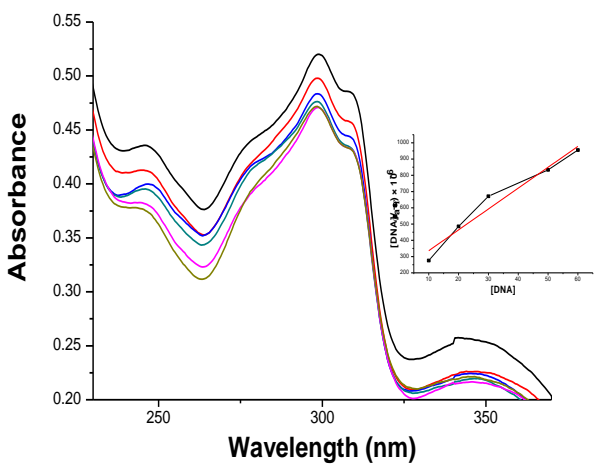

CubpyDox 2

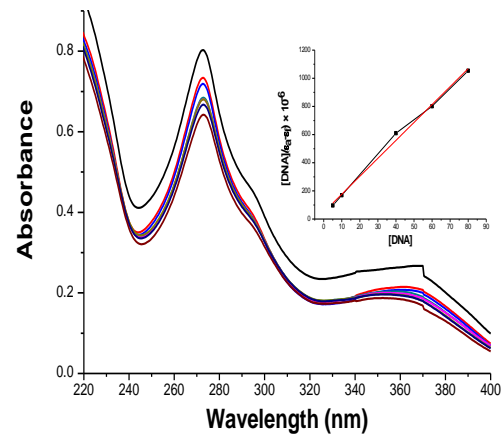

CubpyDox 3

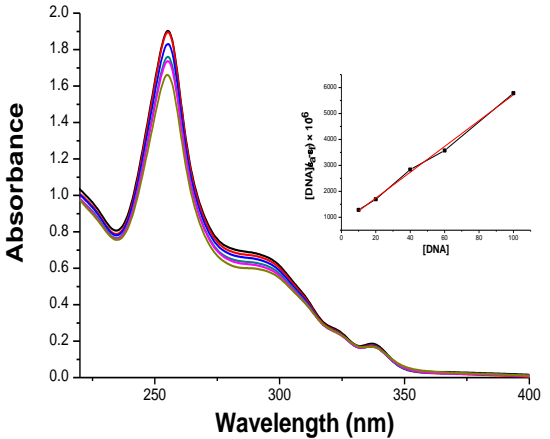

CubpyDox 4

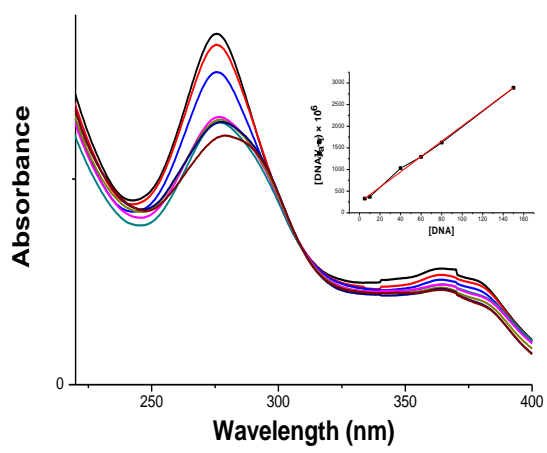

CubpyDox 5

Fig.2: Graphs showing the electronic absorption spectra of complexes 2,3,4 and $5(20 \mu M)$ with increasing concentrations of CT-DNA in $50 \mathrm{mM} \mathrm{NaCl}$ and $5 \mathrm{mM}$ Tris $\mathrm{HCl}$ buffer at $\mathrm{pH} 7.2$.

Thermal melting experiments

Thermal melting temperature $\left(\mathrm{T}_{m}\right)$ of DNA is the temperature at which half of DNA strands dissociates from double-stranded to single-stranded DNA state. The DNA melting experiment provides information about the stability of the DNA helix. The $\mathrm{T}_{m}$ of DNA in the absence of any external agent was found to be $62.7^{\circ} \mathrm{C}$. Under the same experimental conditions and in the presence of complexes 2-5, $\Delta \mathrm{T}_{\text {mvalues }}$ are $0.7,3.8,2.0$ and $2.4{ }^{\circ} \mathrm{C}$ respectively. These values of $\Delta \mathrm{T}_{m}$ for the complexes obviates the possibility of intercalative binding of the complexes to DNA. Generally, the binding of metal complexes with DNA stabilizes the double helix structure which usually results in huge increase in Tm of DNA for DNA intercallators. The modest values of $\Delta \mathrm{T}_{\mathrm{m}}$ (between +0.7 and $+3.8{ }^{\circ} \mathrm{C}$ ) by complexes 2-5support a non-intercalative binding mode for 
the complexes. Stabilization of $+5.2^{\circ} \mathrm{C}$ was reported for poly $\left[\mathrm{d}(\mathrm{G}-\mathrm{C})_{2}\right]$ by methyl green, a major groove binder. This result confirms that the complexes are major groove binders and is in agreement with the DNA binding constants obtained for the complexes.

\section{Viscosity Measurements}

Viscosity is an effective method to distinguish between modes of binding of small molecules to DNA [74]. For molecules that form bond with DNA, kinking/ bending of the DNA helix toward the minor or major groove leads to a decrease in the viscosity of DNA solution as a result of reduction in the end-to-end length of the DNA. However, groove binders do not alter the end-to-end length of DNA and therefore have negligible effect on viscosity of DNA solution while intercalation results in lengthening, unwinding and stiffening of the helix causing a significant increase in viscosity of DNA solution [74].

The addition of complexes $\mathbf{2 - 5}$ to CT-DNA did not alter its solution viscosity indicating that the mode of binding of the complexes is groove binding. Because changes in relative viscosity can be used in assigning DNA binding modes by intercalators [75-76], the data confirm that the complexes do not intercalate between the DNA bases.Other nonintercalative complexes of polypyridyl ligands have been previously reported [77-81].

\section{CONCLUSIONS}

Five new single and mixed ligand copper (II) complexes of doxycycline and polypyridyl ligands have been tested as DNA binding agents by UV-Vis titration, viscosity and thermal melting experiments. Data from thermal melting profile and viscosity measurements reveal that the compounds moderately stabilize CT-DNA as major groove binders. The binding constants of the complexes are $7.26 \times$ $10^{4}, 6.7 \times 10^{4}, 2.58 \times 10^{5}$ and $6.18 \times 10^{4}$ for complexes $\mathbf{5}$, 4,3 and 2 respectively as evidenced by electronic titration.. This substantiates the non-intercalative binding abilities of polypyridyl ligands complexes to DNA through the major groove. The bulky ancillary ligand doxycycline must be responsible for the major groove binding abilities of these complexes.

\section{ACKNOWLEDGEMENT}

The authors appreciate STEP-B project and University of Ilorin for financial support; OOA appreciates The World Academy of Science (TWAS) and DBT- India for Postgraduate Fellowship (FR number: 3240240274) to Savitribai Phule Pune University, Pune, India.

\section{REFERENCES}

[1] M. O. Griffin, E. Fricovsky, G. Ceballos, and F. Villarreal, 2010, Am J Physiol Cell Physiol299, C539_ C548

[2] B. M. Duggar, Ann. New York Acad. Sci.,1948, 51, 177.

[3] R. W. Broschard, A. C. Dornbush, S. Gordon, B. L. Hutchings, A. R. Kohler, G. Krupka, S. Kushner, D. V. Lefemine, and C. Pidacks, Science,1949,109, 199.

[4] A. C. Finlay, G. L. Hobby, S. Y. P'an, P. P. Regna, J. B. Routien, D. B. Seeley, G. M. Shull, B. A. Sobin, I. A. Solomons, J. W. Vinson, and J. H. Kane, Science, 1950,111,85.

[5] P. P. Regna, I. A. Solomons, K. Murai, A. E. Timreck, K. J. Brunings, and W. A. Lazier, J. Amer. Chem. Soc.,1951, 73, 4211.

[6] L. H. Conover, W. T. Moreland, A. R. English, C. R. Stephens, and F. J. Pilgrim, J. Amer. Chem. SOC., 1953,75, 4622-4623.

[7] J. H. Boothe, J. Morton, jun., J. P. Petisi, R. G. Wilkinson, and J. H. Williams, J. Amer. Chem. Soc., 1953,75,4621.

[8] P. P. Minieri, M. C. Firman, A. G. Mistretta, A. Abbey, C. E. Brickler, N. E. Rigler, and H. Sokol, 'Antibiotics Annual 1953-1954', Medical Encyclopedia, Inc., New York, 1953,p. 81.

[9] D. Schnappinger, nd W. Hillen, Archives of Microbiology, 1996, 165(6), 359-69

[10] A. N. Sapadin, R. Fleischmajer, J Am Acad Dermatol. 2006, 54(2), 258-65.

[11] E. Monk, A. Shalita, D. M. Siegel, Pharmacological Research, 2011, 63(2) 130-145

[12] D. L. J. Clive, Chemistry of Tetracyclines, Clive, D.L.J. Quart. Rev. (London) 1968, 22, 435-456

[13] W. Durkheimer, Angewandte Chemie, 1975, 14(11), 721-774

[14] M. G. Charest, C. D. Lerner, J. D. Brubaker, D. R. Siegel, A. G. Myers, 2005 Science,308(05), 395-398

[15] D. A. Kummer, D. Li, A. Dion and A. G. Myers, Chem. Sci., 2011, 2, 1710

[16] P. M. Wright, A. G. Myers, 2011, Tetrahedron, 67, 9853-9869

[17] C. Sun, Q. Wang, J. D. Brubaker, P. M. Wright, C. D. Lerner, K. Noson, M. Charest, D. R. Siegel, Y. Wang, and A. G. Myers, J. Am. Chem. Soc. 2008, 130, 17913-17927

[18] J. D. Brubaker and A. G. Myers, Org. Lett., 9(18), 2007, 3523-2525 
[19] M. G. Charest, D. R. Siegel, and A. G. Myers, J. Am. Chem. Soc. 2005, 127, 8292-8293.

[20] Matthias O. Schmitt and Siegfried Schneider, 2000, PhysChemComm, 9, 42-55.

[21] M. O. Griffin, G. Ceballos, F. J. Villarreal, Pharmacological Research63(2), 2011, 102-107.

[22] D. E. Brodersen, W. M. Clemons, Jr., A. P. Carter, R. J. Morgan-Warren, B. T. Wimberly, and V. Ramakrishnan, Cell, 103, 1143-1154, S.B. Levy, L. McMurry Biochem. Biophys. Res. Commun, 1974, 56, 10080-1088.

[23] S.B. Levy, L. McMurryBiochem. Biophys. Res. Commun, 1974, 56, 10080-1088.

[24] L. McMurry, R.E. Petrucci Jr., S.B. Levy, Proc. Natl. Acad. Sci. USA. 1980, 77, 3974-3977.

[25] L. McMurry, B.H.Park, V. Burdett, S.B. Levy, Antimicrob. Agents Chemother.,1987,31, 1648-1651

[26] V.Burdett, J. Bacteriol. 1986, 165, 564-569

[27] R. Sanchez-Pescador, J.T.Brown, M. Roberts, M.S. Ureda, Nucleic Acids Res., 1998, 16, 1218

[28] S.R.Connel, D.M. Tracz, K.H. Nierhaus, D.E. Taylor, Antimicrob. Agents Chemother. 2003, 47, 3675-3681

[29] N. Ahmad, J. Safder, and C. Munir, Monatsheftefu̇̀ r Chemie, 1999,130, 267-274

[30] C. M. Mikulski, J. Fleming, D.H. Fleming Inorganica Chimica Acta, 1988, 144, 9-16

[31] F.C.S. de Paula, S. Carvalho, H. A. Duarte, E. B. Paniago, A. S. Mangrich, E. C. Pereira-Maia, Journal of Inorganic Biochemistry, 1999, 76, 221-230

[32] W. Guerra, E. de Andrade Azevedo, A. R. de Souza Monteiro, M. Bucciarelli-Rodriguez, E. ChartoneSouza, A. M. A. Nascimento, A. P. S. Fontes, L. L. Moyec, E. C. Pereira-Maia, Journal of Inorganic Biochemistry,2005, 99, 2348-2354

[33] P. P. Silva, W. Guerra, J. N. Silveira, A. M. C. Ferreira, T. Bortolotto, F. L. Fischer, H. Terenzi, A. Neves, and E. C. Pereira-Maia, Inorg. Chem., 2011, 50 (14), 6414-6424

[34] T. Bortolotto, P.P. Silva, A. Neves, E.C. Pereira-Maia, and H. Terenzi, Inorganic Chemistry, 201150 (21), 10519-10521.

[35] R. H. Lindberg, P. Wennberg, M. I. Johansson, M. Tysklind, and B. A. V. Andersson,Environ. Sci. Technol., 2005, 39 (10), 3421-3429

[36] I.G. Casella and F. Picerno, J. Agric. Food Chem., 2009, 57 (19), 8735-8741
[37] K. R. Solomon, D. G. Hillis, L. Lissemore, P. K. Sibley, 2009, Veterinary Pharmaceuticals in the Environment, Chapter 13, 191-204.

[38] W. Chen and C. Huang, Environ. Sci. Technol. 2009, 43, 401-407.

[39] M. W. Olson, A. Ruzin, E. Feyfant, T. S. Rush III, J. O'Connell and Patricia A. Bradford, Antimicrobial Agents and Chemotherapy, 2006, 50 (6), 2156-2166.

[40] J. Cazalis, S. Tanabe, G. Gagnon, T. Sorsa, D. Grenier, Inflamation, 2009, 32(2), 130-137.

[41] E. L. Dahl, J. L. Shock, B. R. Shenai, J. Gut, J. L. DeRisi, and P. J. Rosenthal, Antimicrobial Agents and Chemotherapy, 2006, 50(9), 3124-3131.

[42] Y. Liu, M. E. Ryan, H. Lee, S. Simon, G. Tortora, C. Lauzon, M. K. Leung and L. M. Golub, Antimicrob. Agents Chemother., 2002, 46(5), 1447-1454.

[43] M. C. Roberts, Clinical Infectious Diseases, 2003, 36, $462-7$.

[44] Z. Saikalia and G. Singh, Anti-Cancer Drugs, 2003, 14,773-778.

[45] K. Son, S. Fujioka, T. Iida, K. Furukawa, T. Fujita, H. Yamada, P. J. Chiao and K. Yanaga, Anticancer Research, 2009, 29 (10), 3995-4003.

[46] J. Liu, C. A. Kuszynski, B.T. Baxter, Biochemical and Biophysical Research Communications, 1999, 260 (2), $562-567$.

[47] R. S. Fife, B. T. Rougraff, Proctor C, G. W. Sledge Jr., J Lab Clin Med, 1997, 130, 530-534.

[48] L.Shen, Y. Chen, L. Lin, S. Shaw, Oral Oncology, 2010 46, 178-184.

[49] K. Inoue, T. Sone, C. Oneyama, F. Nishiumi, H. Kishine, Y. Sasaki, T. Andoh, M. Okada, J. D. Chesnut and F. Imamoto1, Gene Therapy, 2009, 16, 1383-1394.

[50] M. E. Ryan, A. Usman, N. S. Ramamurthy, L. M. Golub, R. A. Greenwald, 2001, Curr Med Chem,8, 305-316.

[51] S. Briolant, L. Almeras, M. Belghazi, E. BoucomontChapeaublanc, N. Wurtz, A. Fontaine, S. Granjeaud, T. Fusaï, C. Rogier and B. Pradines, Malaria Journal 2010, 9, 141.

[52] Yoshiki Miyachiㄴ, Akira Yoshioka 1 , Sadao Imamura 1 and Yukie Niwa, Journal of Investigative Dermatology, 1986, 86, 449-453.

[53] L. F. Bastos, L. A. Merlo, L. T. Rocha, M. M. Coelho, Eur J Pharmacol, 2007, 576, 171-179. 
[54] R. L. Kraus, R. Pasieczny, K. Lariosa-Willingham, M. S. Turner, A. Jiang and J. W. Trauger, Journal of Neurochemistry, 2005, 94, 819-827.xxx

[55] W. C. M. Duivenvoorden, S. V. Popovic', S. Lhotak, E. Seidlitz, H. W. Hirte, R.G. Tozer, and G. Singh, Cancer Research, 2002, 62, 1588-1591.

[56] R. S. Fife, G. W. Sledge Jr., J Lab Clin Med., 1995 125(3), 407-11.

[57] R.S. Fife, G.W. Sledge, B.J. Roth, C. Proctor, Cancer Lett. 1998 127(1-2), 37-41.

[58] M .Takahashi, L. Altschmied, W. Hillen, J MolBiol,19861,87, 341-348.

[59] R. A. Goldman, T. Hasan, C. C. Hall, W. A. Strycharz, B. S. Cooperman, Biochemistry,1983, 22, 359-368,.

[60] M. E. Ryan, A. Usman, N. S. Ramamurthy, L. M. Golub, R. A. Greenwald, 2001, Curr Med Chem,8, 305-316.

[61] W. C. Duivenvoorden, H.W. Singh, Invasion Metastasis, 1997; 17(6), 312-322.

[62] S. S. Bhat, A. A. Kumbhar,H. Heptullah, A. A. Khan ,V. V. Gobre, S. P. Gejii, V. G. Puranik, Inorg. Chem., 2011, 50 (2), pp 545-558.

[63] MasayukiTakahashi,Journal of Molecular Biology, 1986,187(3), 341-348.

[64] A. Kellett,M. O’Connor,M. McCann,M. McNamara,P. Lynch,G. Rosair, V. McKee,B. Creaven,M. Walsh,S. McClean,A. Foltyn,D. O'Shea, O. Howeand M. Devereux, Dalton Trans., 2011, 40, 1024.

[65] S. Ramakrishnan, D. Shakthipriya, E. Suresh, V. S. Periasamy, M. A. Akbarsha, and M. Palaniandavar, Inorg. Chem., 2011, 50, 6458-6471.

[66] J. Wang,Q. Xia,X. Zheng,H. Yan Chen,Hui Chao,Z. Mao, and L. Jia, Dalton Trans., 2010, 9, 2128-2136.

[67] J.G. Collins, A.D. Sleeman, J.R.Aldrich-Right, Greguric I, T.W.Hambley, Inorg. Chem., 1998, 37, 3133-314.

[68] C.M. Dupureur and J.K. Barton, Inorg. Chem., 1997, 36, 33.43 .

[69] O.O. Abosede, N.A. Vyas, S. Singh, A.S. Kumbhar, A. Kate, A.A. Kumbhar, A. Khan, A. Erxleben, P. Smith, C.de Kock, F. Hoffmann, J.A. Obaleye, (2016). Copper (II) Mixed Ligand Polypyridyl Complexes with Doxycycline- Structures and Biological Evaluation, Dalton Trans., 45: 3003-3012.

[70] V.A.Kawade, A.A.Kumbhar,A.S. Kumbhar, C.Nather, A.Erxleben, U.B.Sonawane, and R.R.Joshi, Dalton Transactions, 2011,40,639.
[71] C.V.Kuman, E.H.Asuncion,J. Am. Chem., 1993, 115, 8547.

[72] A.Wolfe, G.H.Shimer, T.Meehan, Biochemistry, 1987, 26, 6392-6396

[73] M.S. Deshpande, A.A. Kumbhar, A.S. Kumbhar, M. Kumbhakar, H. Pal, U.B. Sonawane, R.R. Joshi, BiconjugateChem., 2009, 20, 447.

[74] MeniWanunu, Yitzhak Tor, 2012, Methods for Studying Nucleic Acid/Drug Interactions Taylor and Francis, 29.

[75] D.Suh, Y.-K.Oh, J. B. Chaires, Process Biochem. 2001, 37, 521 .

[76] I.Haq,; P.Lincoln,; D.Suh,; B.Norden,; B. Z.Chowdhry,; J. B. Chaires, J. Am. Chem. Soc. 1995 , $117,4788$.

[77] A.M. Angeles-Boza, P.M. Bradley, P.K.-L. Fu, M. Shatruk, M. G. Hilfiger, K. R. Dunbar and Claudia Turro, Inorganic Chemistry, 2005, 44(21), 7262-7264.

[78] A.M. Angeles-Boza, P.M. Bradley, P.K.-L. Fu, S.E. Wicke, J. Bacsa,K.R. Dunbar, and C. Turro, Inorganic Chemistry, 2004, 43 (26), 8510-8519.

[79] P. Waywell, V. Gonzalez, M. R. Gill, H. Adams, A. J. H. M. Meijer, M. P. Williamson, and James A. Thomas, Chem. Eur. J. 2010, 16, 2407 - 2417.

[80] T. Gupta, S. Dhar, M. Nethaji and A. R. Chakravarty, Daltons Trans, 2004, 18, 1896-1901

[81] A. Ghosh, P. Das, M. R. Gill, P. Kar, M. G. Walket, J. A. Thomas and A. Das, 2011, 17, 2089-2098. 